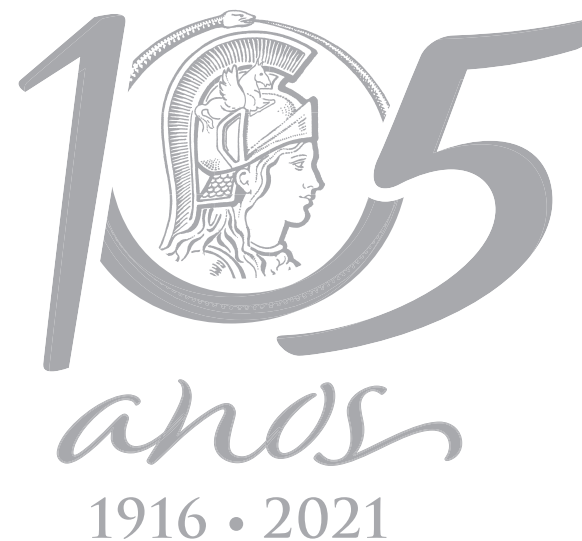

$1916 \cdot 2021$

\title{
From Spanish Flu to Syndemic COVID-19: long- standing sanitarian vulnerability of Manaus, warnings from the Brazilian rainforest gateway
}

\author{
SÉRVIO P. RIBEIRO, ALEXANDRE B. REIS, WESLEY DÁTTILO, ALCIDES V.C. \\ DE CASTRO E SILVA, EDUARDO AUGUSTO G. BARBOSA, WENDEL COURA- \\ VITAL, ARISTÓTELES GÓES-NETO, VASCO A.C. AZEVEDO \& GERALDO WILSON \\ FERNANDES
}

\begin{abstract}
A second deadlier wave of COVID-19 and the causes of the recent public health collapse of Manaus are compared with the Spanish flu events in that city, and Brazil. Historic sanitarian problems, and its hub position in the Brazilian airway network are combined drivers of deadly events related to COVID-19. These drivers were amplified by misleading governance, highly transmissible variants, and relaxation of social distancing. Several of these same factors may also have contributed to the dramatically severe outbreak of H1N1 in 1918, which caused the death of 10\% of the population in seven months. We modelled Manaus parameters for the present pandemic and confirmed that lack of a proper social distancing might select the most transmissible variants. We succeeded to reproduce a first severe wave followed by a second stronger wave. The model also predicted that outbreaks may last for up to five and half years, slowing down gradually before the disease disappear. We validated the model by adjusting it to the Spanish Flu data for the city, and confirmed the pattern experienced by that time, of a first stronger wave in October-November 1918, followed by a second less intense wave in February-March 1919.
\end{abstract}

Key words: SARS-CoV-2, Tropical urban health, Ecohealth, Native communities, modelling disease dissemination, Manaus.

\section{INTRODUCTION}

Historical investigations and mathematical predictive models are methods to search out solutions for upcoming problems. A complex network model simulating Brazilian flightinterconnected cities as a metapopulation structure was published by Ribeiro et al. (2020a). That study explored the number of flights as a driver for SARS-COV-2 dissemination, based on a SIR-adjusted model. The study correctly predicted which were the crucial international and national hub airports in Brazil, as well as the sequence of cities to be hit by the pandemic in the subsequent weeks, anticipating each actual city infection date by seven to 14 days. The persistence of the disease in São Paulo, Rio de Janeiro, and Manaus were also explained by this ecologically neutral model (Ribeiro et al. 2020a).

For several reasons, the world failed to refrain the spreading of SARS-CoV-2, and, in Brazil it followed the most expected neutral pattern (i.e., it followed the most used routes and spread with no contention towards the whole country, Ribeiro et al. 2020b). Antiscientific discourse and misleading actions prevented any control of the disease arrival and its subsequent spreading 
in Brazil, as well as delayed and undermined control after community transmission was in place (Fraser 2020). Nevertheless, cultural aspects, poverty, and inadequately planned and overcrowded tropical cities, such as Manaus, might most likely ended up having the pandemic arrival turned into a syndemic problem, eventually longer and more severe than it needed to be.

Herein we explored the dynamics related to the urban spreading of the COVID-19 and evaluated the intricate history of urban behaviours and politics affecting public health guidance during a pandemic. For such, we used Manaus as a model, and explored how the social, political-driven environment, and undermining of scientific facts left the city fully vulnerable to the exposition of more transmissible variants and a longer recurrent pandemic. Manaus was selected because its first COVID-19 outbreak was sufficiently vast to raise the hypothesis that the city could have reached the herd immunity (Buss et al. 2021), which had to be completely revisited when a second and deadlier wave returned early in 2021 (Sabino et al. 2021). Furthermore, Manaus was hit harder than previously expected, having the double of mortality rate than the rest of the country (FVS/MSa 2020), even considering it to be a very interconnected travelling route. Moreover, the same pattern had happened before, during the Spanish Flu, which caused the death of $10 \%$ of Manaus inhabitants, a much higher rate than the $0.12 \%$ national rate (Gama 2020, ATLAS FVG 2021).

In this review, we first described the facts related to the two first waves of COVID-19 in Manaus and compared with the historical facts related to the Spanish Flu in this city, in order to discuss both past and present social and urban scenarios and fragilities. Secondly, based on the assumption that lack of political guidance would lead to an uncontrolled epidemiologic dynamic, including favouring the spread of new more transmissible viral mutants, we mathematically simulated Manaus exposed to both COVID-19 and Spanish Flu. Finally, we used the same algorithm to simulate a competitive scenario with all the combinations of more transmissible and more lethal variants. The ecology of emergent viral diseases, from the dissemination to the natural selection towards higher transmissibility, and scenarios for the natural ending of the pandemic, at the scale of one city, were verified by our mathematical modelling and discussed in this context of a misleading guidance of the disease progression.

\section{MANAUS COVID-19 SECOND WAVE AND PUBLIC HEALTH COLLAPSE}

Manaus showed the first public health collapse in Brazil by April 2020 (precisely, the peak of deaths happened in the epidemiological week 17, 19-25 April - FVS/AMb 2021), as predicted by the model built by Ribeiro et al. (2020a). Warnings from science were especially bold about the vulnerability of Native communities in the Amazon, and the urgency to restrict flights and impose a severe control to the Manaus airport since the city is also the main hub for fluvial transport (Ribeiro et al. 2020a, OBSERVATÓRIO COVID-19 2021). Months after the first collapse, by early January 2021, Manaus had entire hospital blocks with patients dying due to lack of oxygen, dozens of COVID-19 patients being sent to other Brazilian States by the army, and 60 premature babies under the risk of death by the competition for oxygen used to COVID-19 patients. One week after, a shortage of oxygen was reported in other cities in the Amazon region (OBSERVATÓRIO COVID-19 2021). After one month, the lack of oxygen and public health collapse continued, and, by early March, simultaneously, 
nine out of the 27 Brazilian States displayed more than $90 \%$ of occupation of intensive care units, and 18 States exhibited occupation above $80 \%$, according to the Fundação Instituto Oswaldo Cruz FIOCRUZ report (OBSERVATÓRIO COVID-19 2021). FIOCRUZ also reported to the press by that same date, that about half of the tested cases in the nine aforementioned states belonged to highly transmissible variants, those with the E484K mutation. Either the Gamma P.1, the Alpha B.1.1.7 or the Beta B.1.351 were frequently found. This outcome might confidently be associated to the total lack of airport effective surveillance in the country, political undermining of social distancing, masks, and lockdown (OBSERVATÓRIO COVID-19 2021).

The second week of March came with more than 2,000 deaths per day and with a forecast of 3,000 deaths per day until April. Nevertheless, unfortunately, the federal government still maintained a position against lockdown and port controls. Additionally, questionable policies in another area, environment, raised deep health concerns among scientists. By weakening environmental law enforcement, which has been pointed out as the main cause of deforestation in the Amazon (Barbosa et al. 2020), the federal government may bring the region close to the risk of overlapping COVID-19 with future emergent zoonoses, which could occur as a result of environmental disruption (Jones et al. 2008, Karesh et al. 2012). Currently, many cases of COVID-19 among Native communities were spread from clandestine miners and land invaders, acting confidently on a lack of punishment (COVID-19.SOCIOAMBIENTAL 2021).

Ribeiro et al. (2020a, b) models predicted that hub airport cities are unlikely to succeed in controlling the number of cases unless they control passenger arrivals. This is valid for cities as New York and London, or Rio de Janeiro and São Paulo, but also valid for the smaller cities, such as Manaus, with 2 million inhabitants. Furthermore, the constant adding of new infected individuals from the Manaus airport found a quite particular city for community spread. Eventually, a similar political behaviour might have produced a terrifying scenario during the Spanish flu in Manaus.

\section{A TROPICAL BELLE ÉPOQUE CITY AND ITS RESILIENT SANITARIAN VULNERABILITIES UNTIL PRESENT DAYS}

Manaus reflects many of the country's political problems, along with a very particular way of life. It is a complex city for public health, largely due to its expansion along the banks of the Negro River, intrinsically linked to the harbour activity, and entangled with poverty. In November to December the river floods and can even reach downtown streets. The river seasonal dynamics adds to a hygienically compromised environment in the harbour. By having densely populated margins, and mostly lacking sewage treatment, flooding events could spread contaminated water even farther (and created habitats for insect vectors), increasing overall health vulnerabilities in a seasonal way. The context of having many people exposed to other diseases may have contributed to both Spanish Flu and COVID-19 outbreak severities, which occurred in the same months of rains and flooding, despite being separated by 102 years. In spite of few reported studies, Caldas \& Pozzetti (2017) described that there are no monitoring protocols to assess the quality of water applied to the harbour, nor a cleaning and disinfection daily program.

The poor urban sanitary policy is historical and led the city to a previous epidemiological collapse during the Spanish flu pandemic in 1918, when $10 \%$ of the total population died 
within seven months. Gama (2020) described trucks transporting putrefied bodies left on the streets, as there was no space in cemeteries (curiously, the author described that newspapers reported an anti-malarian quinine-based drug proposed as a cure, which disappeared from the pharmacies' shelves by that time). A deadly combination of idiosyncrasies in the Manaus urbanization and social vulnerability made it highly vulnerable to the Spanish flu (Fig. 1). It is already well understood that socioeconomic problems, slums, and spatial distribution of poverty in a city are highly influential determinant of the incidence and distribution of COVID-19 (Buckley 2020, Maroko et al. 2020, Mishra et al. 2020, Mena et al. 2021), along with undermining non-pharmaceutical interventions (Ferrante et al. 2021). The same may have intensified Spanish Flu back in 1918 (Schwarcz \& Starling 2020).

These sanitarian temerities overpass the harbour and repeat in the markets and downtown public areas. Also, a large number of persons live in their boats, usually anchored in bays with stagnant water, where their wastes are dumped with absolutely no treatment, and from where most of them collect water for their consumption, cooking, bathing, etc. Such behaviours towards the river waters, likely born in remote regions, are common among Amazonian river towns. Hence, not only SARSCoV-2 but also secondary infections may spread quickly, which is a serious concern considering overload cemeteries due to excess of bodies along the pandemic. From the Manaus port, the "gaiolas", bird-cage boats, normally leave towards many cities, literally "packed with passengers". Regardless of being open boats, dozens sleep in hammocks side by side, in the same space where they eat. From Manaus to Belém (the largest and most populated cities of Brazilian Amazon region), for instance, the trip usually takes six days, which is a very simple explanation for how both Spanish Flu and COVID-19 fastly spread along the river cities after Manaus had previously started community transmission (Gama 2020, TRANSPARÊNCIA COVID-19 2021).

Hence, without strong sanitarian rules and governmental guidance, it is hard to enforce changes in behaviours based on strong and ancient cultural background, and traditions of close physical contacts. In many of these aspects, Manaus is no different from the rest of Brazil, the city just got hit earlier and stronger, and its unfortunate example should be used as a bold warn for the rest of the country.

\section{THE SIMULATION OF COVID-19 AND SPANISH FLU DYNAMICS IN MANAUS AND NATURAL SELECTION DRIVING THE PANDEMIC INTENSITY AND DURATION}

Mathematical predictions on host-parasite interactions (May \& Anderson 1983) may help to disentangle the causes and consequences of human behaviour versus virion evolutionary determinism in the output of cases and deaths. We explored the combined effects of a soft social isolation, which is currently applied to some Brazilian cities, and the appearance of new more transmissible variants, using Manaus parameters. We applied the same model for the Spanish Flu in order to validate it, using available historical data. Finally, it was simulated the natural evolution of the disease with competing variants in one city that takes no precautions, but still has a certain amount of self-isolated individuals. The program algorithm is described as a Supplementary Table, available at https:// github.com/leaflaboratory/COVID-19-selectionModel/blob/main/Manaus_def.cpp.

We simulated Manaus 2020-21 as an intensely interconnected medium size city, of 


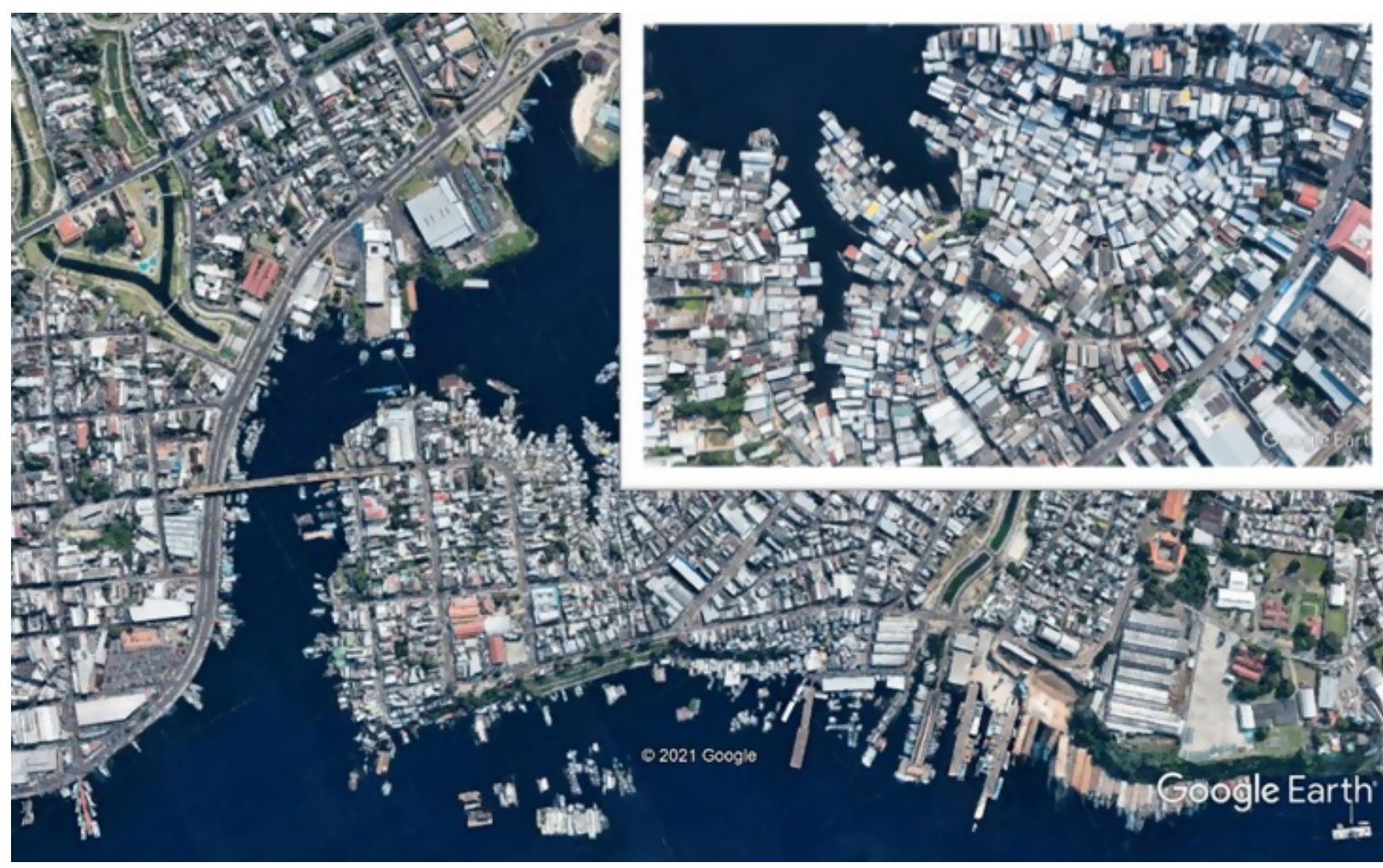

Figure 1. Large picture shows a channel reaching Negro river in Manaus, and some features of the urbanization around the harbour region. Detailed picture focused on a packed and convoluted under poverty neighbourhood, with floating houses in a small channel with stagnated water. An unlikely urbanization for effective social distancing and public areas cleaning. Obtained from Google Earth.

2,000,000 inhabitants and a daily turnover of $0.7 \%$ of its population (which is a proxy of its airport daily movement plus fluvial and road travellers). From these constantly arriving of people, we randomly defined $3 \%$ infected with the original virus strain (i.e.: already circulating in the city), or with a variant 2.6 times more transmissible than the former, simulating the Gamma P1 variant as described in Coutinho et al. (2021). Thus, we simulated a sudden appearance of Gamma, whatever its real origin. The city was designed as a lattice model, with explicit public places of different sizes (thus, with distinct carrying capacity), and one private size for houses, capable to accommodate 3.3 persons (sorted following Poisson distribution). People were randomly sorted to stay home (conservatively at 60\%) and the remaining to move around, visiting several public areas by random, and staying out for 8 hours. We then run an adapted SIR model with contrasting $\beta$-infection rates for each variant (reflecting the greater variance of Gamma, as previously described, S.1). $\beta$-infection rate is the infection constant that represents the proportion of encounters between an infected and a susceptible person, which result in the infection of the latter. Infection occurs when a susceptible person shares a public space with an infected one, with a chance proportional to the $\beta$ of each variant, and to the density of infected and susceptible people in the same place. After five days of incubation, the person became a source of virus and infected others for the following 14 days, unless she/he died, which happened for $1 \%$ of the infected ones (considering recent 
estimates of asymptomatic persons - Loannidis 2020, and their transmissibility - Johansson et al. 2021). After recovery, a person maintained his/ her immunity for 180 days and after returned to the susceptible stage, except for $4 \%$ whom maintained immunity for 360 days, and 5\% that stayed immune forever. Thus, we attempted to reproduce the variance in immunity observed between those with light and heavy symptoms (Stephenson et al. 2021).

Based on historical records taken from both Gama (2020) and Schwarcz \& Starling (2020), we used the same model to simulatea1918-19 Manaus under the H1N1 outbreak: 60,000 inhabitants, three days of incubation after infected, and six days transmitting the virus. Based on the epidemiological descriptions of the Influenza's mortality and Rt (Taubenberger \& Morens 2006, Andreasen et al. 2008), we calculated $\beta$ and run the model with the parameters: $\mathrm{Rt}=5.4$ (Rt as the number of persons infected by one infected person) and $\beta=0.92$. Based on the reports from these authors, hardly any social distancing was observed except for closing down schools, public services, and theatres. Hence, we have assumed a conservative social distancing of $20 \%$. We also assumed in the SIR model that immunity was retained by three months, to simulate the fact that this influenza virus mutated much faster than coronavirus (Day et al. 2020), and that the city may have been hit by various new variants from Europe since the onset of Spanish flu pandemic (Schwarcz \& Starling 2020). According to Schwarcz \& Starling (2020), the dissemination of the Flu towards and at Manaus was as such: in 09 October the city of Belém, Para State, the first Amazonian harbour near the ocean, had 3,000 infected people, from where the ship "Ceará" left to Manaus with infected passengers; 28 October the vessel Valparaiso reached Manaus with individuals suffering of a more severe version of the disease; 02 November hospitals had no bed for flu patients anymore and one week after the officials reported 1,000 infected people; by 14 November the funerary services reported 33 deaths in one day, above the average of five per day, a number that stabilized above 40; the first newspapers articles describing corpses left in the streets arrived by this same day, and the municipality started a service of collecting the dead in a truck, heading to a collective graveyard; by December officials reported 1,500 deaths in November, but Gama (2020) pointed out that this was from official cemeteries, and that unofficial burials in the backyards, and several corpses just thrown in the Negro river would summed up from 6,000 to 8,000 (Schwarcz \& Starling 2020); in February and March 1919 new cases and deaths increased again but with much less strength in the city; reports of disappearance of whole ethnic groups, as the Avá-canoeiro, occurred in early 1919, along with reports of cases in riverside cities, such as Tefé, Maués, Parintins.

The artificialities of the model, for sake of simplicity, are as follow: there is no overlapping infections, immunity and susceptibility are equal to both variants (for COVID-19), and travelling time within the city was taken as irrelevant. Furthermore, there is no age structure, and all have equal chances to get infected. Hence, this model emphasizes the transmissibility by pre-symptomatic and asymptomatic, as no constraint in the movement of an infected person is imposed but when someone dies.

\section{COVID-19 simulation}

Our model for COVID-19 described a several years long-lasting epidemic, with an unavoidable second wave stronger than the first, and continuous new waves, in spite of being gradually weaker along time (Fig. 2). Nonetheless, the second wave and following outbreaks were virus variant-dependent, since 


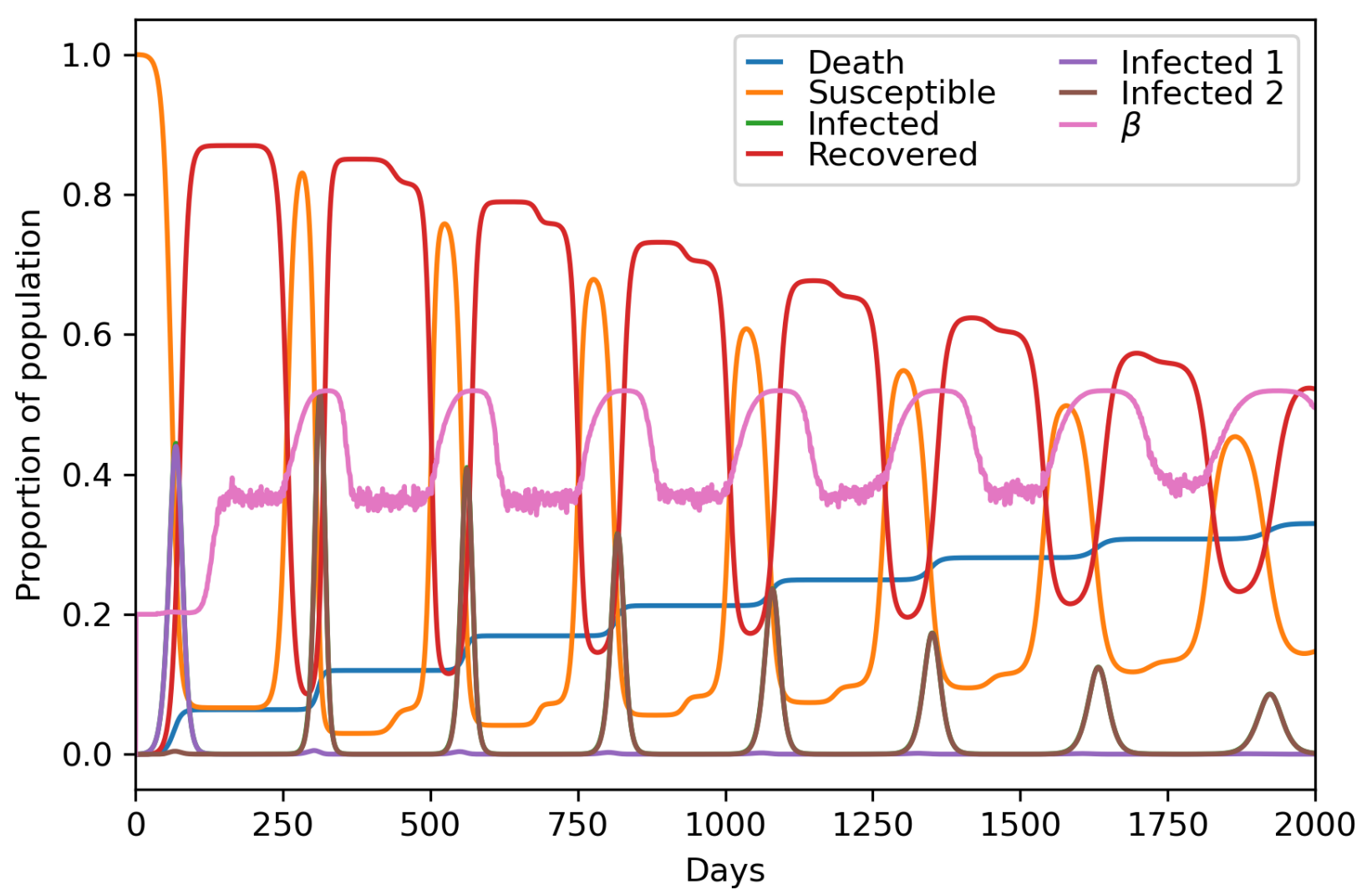

Figure 2. SIR adjusted dynamic of COVID-19 evolution along 2,000 days, adjusted for the Manaus population, migration rates, and original (Infected 1, blue line) and Gamma P1 (Infected 2, orange line) variants. $\beta$ (green line) $=$ combined $\beta$-infection rate for both variants $(\Sigma \beta \mathrm{i} / \Sigma$ infected $)$. Oscilation are due to the variation of number of infected people.

the accumulation of new infections ended up producing a prolonged large proportion of immunized subpopulation, along with the death of those vulnerable individuals. Hence, with little isolation, neither travelling restrictions, nor vaccination, the disease could prevail as long as 2000 days (five and half years) before it becomes unable to produce new relevant outbreak waves. By leaving the disease to die out with time, this city could accumulate a mortality close to $40 \%$ of its population, before death cumulative rates decreases to an irrelevant value.

\section{Spanish Flu simulation}

The model adjusted for the existing conditions in 1918-19, when Spanish Flu hit Manaus and killed $10 \%$ of its population, was able to reproduce the two waves in the exact months they happened (September to November 1918 and February to March 1919), with the first stronger than the second, as it was the case (Fig. 3). Our model predicted $60 \%$ of deaths in the city, but considering the intense flux of people through Manaus, this high value could explain the spreading of the disease in the interior by 1919.

\section{Competition between variant traits simulation}

We also further tested different variants with distinct transmissibility or lethality. The variants with less transmissibility than the original strain were not able to invade the city while the more transmissible variants substituted the original one after 200 days and following a second 


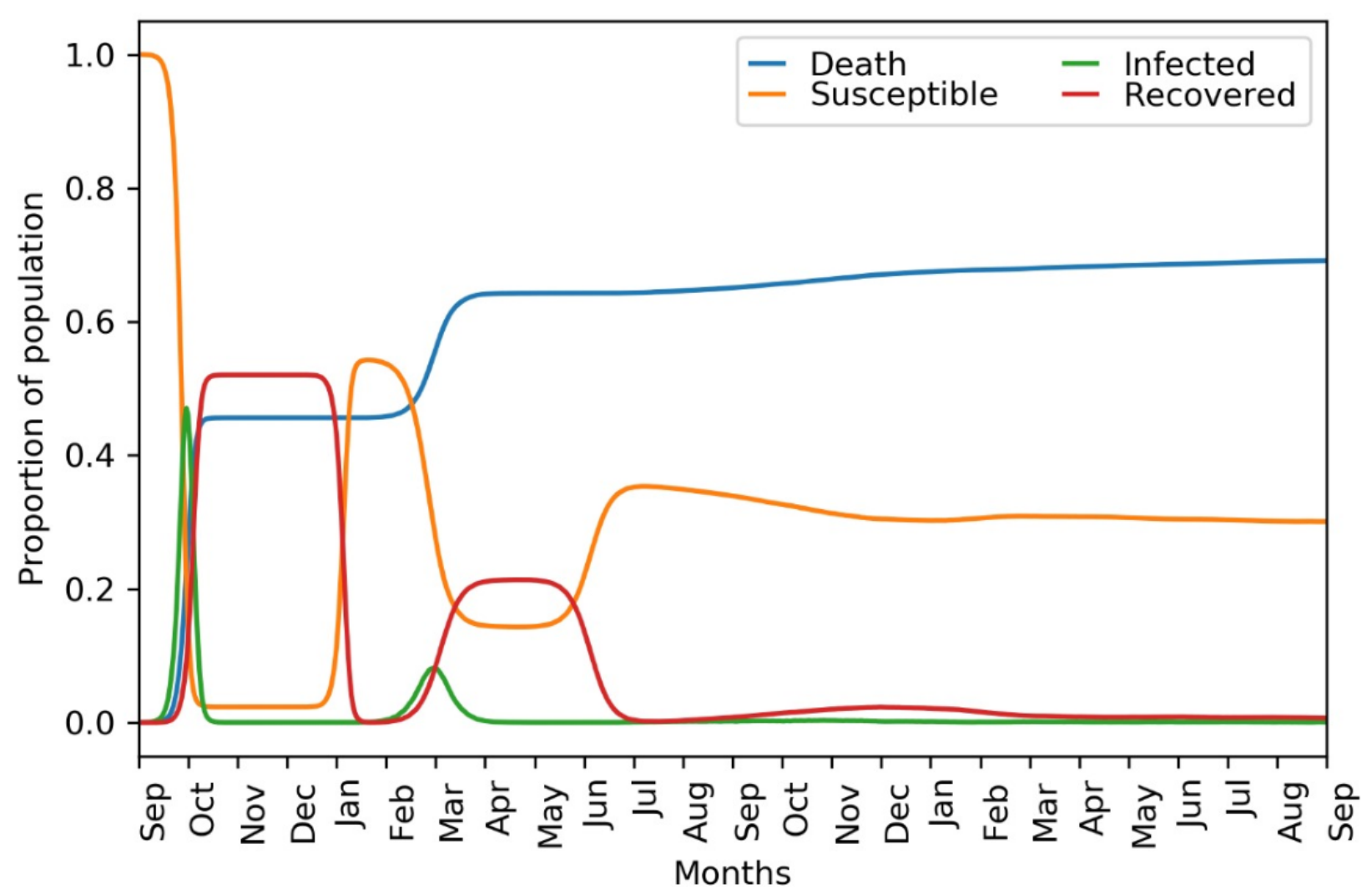

Figure 3. SIR adjusted dynamic of Spanish Flu evolution along the period recorded for its occurrence in Manaus. We assumed only one variant of H1N1 and showed the variables responses to the simulation of the population size and published parameters of mortality and transmissibility for the Influenza 1918-19 (see the text for details).

wave. Interestingly, the lesser lethal variant overcame the more lethal one in all the waves, which is expected for a long-term evolution of an emergent disease if the lack of host illness favours transmission, i.e., loss of virulence (Fig. 4). Due to the full shifting of the original strain by new variants, the $\beta$-infection rate was permanently higher after the second wave than it was in the beginning of the pandemics.

\section{DISCUSSION}

A mathematical model does not aim to reproduce the reality, but to emphasise parameter-driven patterns that could help us understanding the date, intensity, and duration of host-pathogen dynamics. Our simulations reproduced some important dynamics that happened in both
Spanish flu and COVID-19 pandemics in Manaus. A limitation of our model for both pandemic events was that it produced an excessive number of deaths as our simulation reflects movement and isolation from individual to individual but did not consider populational heterogeneity, which may cause transient collective immunity and, thus, retain a larger amount of the population untouched by the virus and, consequently, susceptible (as in Tkachenko et al. 2021). Still, our large number of deaths, for both scenarios, may somehow reflects one particular possibility: the city may become a source of infected travellers in a close regional space, which may keep a certain number of imperceptible cases for much longer than the end of the collapse of the public health, especially in contained outbreaks in poor and forgotten suburbs or in 


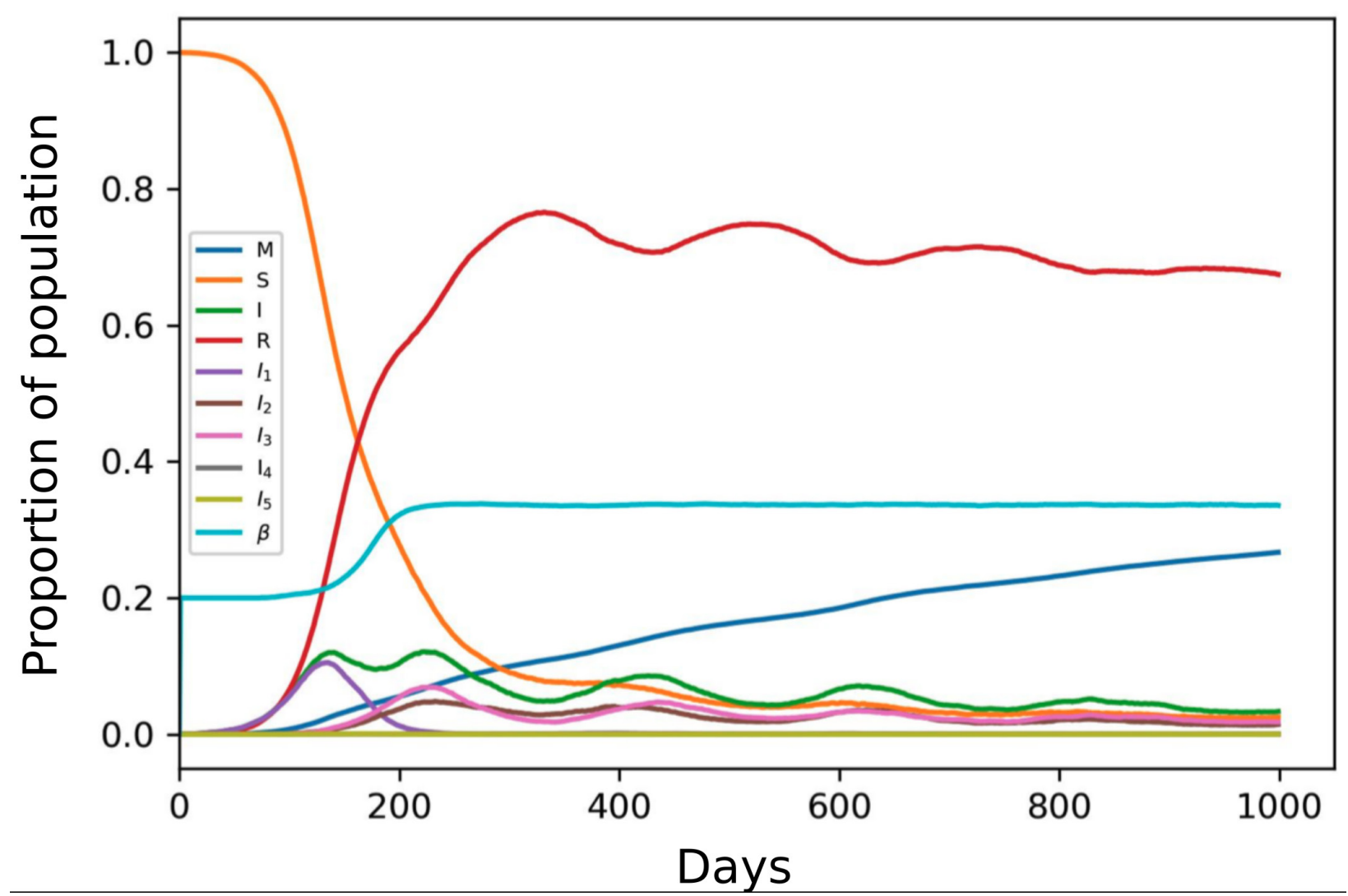

Figure 4. SIR adjusted dynamic of COVID-19 evolution along 1,000 days in a 100,000 simulated town, with $1 \%$ of population turnover with outsider source of persons. $M=$ mortality; $S=$ susceptible; $I=$ infected; $R=$ recovered; $\mathrm{I}_{1}=$ portion of infected population carrying the indigenous strain. In comparison with the indigenous strain: $\mathrm{I}_{2}=$ portion of infected population carrying the variant more transmissible and more lethal; $I_{3}=$ portion of infected population carrying the variant more transmissible and less lethal; $I_{4}=$ portion of infected population carrying the variant less transmissible and more lethal; $I_{5}=$ portion of infected population carrying the variant less transmissible and less lethal; $\beta=$ combined $\beta$-infection rate for all existing variants in a time $t_{i}$. Any less transmissible variants than the indigenous were not able to establish and that most transmissible eliminated the indigenous strain after established. Also, important to note that along the time, the more transmissible and more lethal variant cannot overpass the frequency of the more transmissible but less lethal, pointing toward the evolution of lower virulence along time.

small villages. Indeed, long after Spanish Flu was considered ended in Manaus, March of 1919, several reports of villages with excessive deaths and even indigenous ethnies that have just vanished from civilized contact, were brought about from explorers of the interior (Schwarcz \& Starling 2020).

\section{Causes of a second deadlier wave of distinct pandemics: Spanish flu and COVID-19 in Manaus and Brazil}

If something should be learned from history, the 1918 flu pandemic had a second and more lethal wave worldwide (matching the first wave in Manaus) surged in the middle of lack of information (hidden by war propaganda) and political denials (Taubenberger \& Morens 2006). Many unanswered questions are still in place about the actual driver of a second much more 
severe wave in different pandemics. Unstable and temporary highly pathogenic strains may emerge if a huge number of susceptible hosts are constantly made available during an emerging disease, as predicted by Lenski and May (1994). Hence, neglecting social distancing in the middle of a pandemic might be a driving force for increasing death rates, by favouring both more lethal or more transmissible strains before high transmissibility with low lethality takes a definitive place in the evolution of the disease, and mortality declines for good, if it follows the prediction of May \& Anderson (1983) or Berngruber et al. (2013).

Presently, a similar pattern has repeated worldwide, with families and youngsters not willing to hold in isolation since the 2020 Christmas and 2021 New Year celebrations. In Manaus, the hardest public health collapse happened exactly two weeks after the New Year celebrations. This also coincided with the appearance of a new virulent strain of SARSCoV-2 found in the Amazon, the Gamma P.1. Since then, the daily number of cases is above the average for the whole pandemic period, and an increasing number of hospitalized cases under 60 years old has been reported, even before the vaccination. This was a bold evidence of a more resilient and concerning moment of the pandemic in the region, which is also consistently more lethal among Amazonian Natives (TRANSPARÊNCIA COVID-19 2021).

Most respiratory viral pandemics in history are reported to return in waves, and commonly, the second waves are stronger with several likely explanations for this pattern (Berngruber et al. 2013, Gagnon et al 2013). After a few waves of outbreaks, the disease eventually disappeared, which was the case since the Russian flu (1890), the Spanish flu (1918-19), Asian flu (1957), and the Hong Kong flu (1968). Recent coronavirus outbreaks were caused by viruses with a very high pathogenic capacity and, thus, less likely to produce a pandemic, such as the SARS-CoV and the MERS, which killed above $10 \%$ of infected people. Concerning dissemination, the present SARS-CoV-2 seems to behave more closely to Influenza type A virus, which suggests that transmissibility might be a more important ecological driver of a second wave than virus taxonomical identity, specific infection mechanisms or host immune response.

A recurrent aspect about emergent disease pandemics is that they may disappear with time, as the pathogen adjusts evolutionarily to the new host, by losing lethality or declining to unperceivable levels, as host immunity humps up and more vulnerable host genotypes are eliminated (May \& Anderson 1983, Taubenberger et al. 2000, Reid et al. 2004, Taubenberger \& Morens 2006). Even considering that virulent mutants may be transiently favourable in the early stages of a disease emergence, their tendency is of losing competitivity with highly transmissible variants, which could result in prevalence and low lethality, a hypothesis supported mathematically (May \& Anderson 1983), experimentally (Berngruber et al. 2013), and genetic-and-historically, in the studies of 1918 linages of H1N1 in humans (Taubenberger et al. 2000, Reid et al. 2004, Taubenberger \& Morens 2006). Furthermore, there might have situations when lethality may prevail for longer than expected after a disease invades a new host. A special case is arbovirus diseases, which can sustain virulent strains for decades, as observed for dengue. The insect vector-host is a key aspect for that, namely when vertical transmission in the insect population may be frequent (Ferreira-de-Lima \& Lima-Camara 2018).

Additionally, a large uncertainty raises from the fact that COVID-19 is a disease with a larger proportion of transmission happening 
from pre-symptomatic or fully asymptomatic individuals (Johansson et al. 2021), leading to several possible evolutionary outputs, including the absence of selection against virulence (Day et al. 2020). The possibility of virulence remaining despite selection of more transmissible variants, as indeed was confirmed to the Alpha B.1.1.7 variant (Davies et al. 2021), is a likely scenario for SARS-CoV-2. Nevertheless, if the time spam between infection and death is a key period of transmission, it may result in the mechanism for virulence loss. Among the possible outputs from the models of SARS-CoV-2 evolution in Day et al. (2020), there is substantial theoretical support for selection in favour of a mutant with greater transmissibility without increased lethality. Eventually, even with decreasing the intensity of symptom onset. A mutant prevails if its selection coefficient is positive, and one likely way for such is that it "remains infectious for longer" (Day et al. 2020). Therefore, it is not the neutrality of lethality (i.e., lethality has little evolutionary cost as most transmissions are before symptom), but the advantage of prolonging transmission in a continuously healthy host, the possible driver of increasing transmissibility with decreasing virulence.

A humanitarian problem with leaving a pandemic to run its course is the unbearable life cost, as observed in 1918 influenza pandemic, with certainly more than 50 million people dead out of a world population of 2 billion people. The least lethal a virus is, the more it might kill by silent transmission ( $\mathrm{Li}$ et al. 2020). Hence, the present model tries to predict for how long and which proportion of a population may be taken if a society leaves a pandemic to run to exhaustion.

\section{CONCLUSIONS}

\section{The Brazilian public health and funerary collapses of 2021: predictions and responsibilities}

In a few months of great mortality, the Spanish flu caused a major socio-economic disruption in Brazil from 1918 to 1919. Although much more lethal globally than COVID-19, that pandemic killed a much lower proportion of the population in the, by that time, marginal Brazil (0.12\%), compared with central economies in Europe, Asia, and North America. It killed at least 35,000 out of the 28,900,000 Brazilian population (ATLAS FVG 2021). It was, thus, much more severe in Manaus than in other cities. By June 2021, COVID-19 had already killed more than 500,000 Brazilians, and, thus, over $0.24 \%$ of the $210,000,000$ population, which makes Brazil an unfortunate international outlier. On 12 March, Brazil overpassed India in number of cases, a country with 5.6 more individuals. In these same days, scientists, cemetery managers, and hospital directors were alerting for the worse, in the verge of a collapse in the coming weeks of March and April 2021, which was confirmed. With no clear central government guidance, individuals, institutions, state and city managers were using social and conventional media, trying to overwhelm the federal negligence and contradictory messages. The natural ending of a pandemic is certain, but hardly recorded scientifically (Taubenberger \& Morens 2006), which makes difficult to review on the subject, unless one mix medical literature with historical descriptions, mostly taken from the media, as we did in this study. However, the few articles enlightening the intensity and duration of the Spanish Flu in US, for instance, clearly demonstrated that social distancing and nonpharmaceutical interventions were the best and fastest solutions, both economically as humanitarianly (Hatchett et al. 2007). 
Cities in tropical developing countries are hard to be maintained healthy safe. The unacceptable humanitarian catastrophe of Manaus, twice, and its worry interconnection with Native communities still are our main concerns. A severe restriction to flights and river boats, especially from Manaus to the interior of Amazon and Pará states, is essential to stop the spreading of new variants. Months after the first collapse of 2020, it was proposed that the population in Manaus was above herd immunity (Buss et al. 2021) but that did not prevent them to face a second and stronger wave, nearly one year ahead.

Eventually, this might be the moment to send back the term "herd immunity" to where it belongs: the vaccinology. It is hard to assume in a natural infection process how many persons out of those with moderate or no disease would actually be protected by having produced immunologic memory or, alternatively, be simply resistant (would not get infected at all after exposed). Despite a welldesigned serologic study might help to sort out asymptomatic from susceptible individuals, it does not explain why some will be in contact and not infected (a population component absorbs and simulated by the $\beta$-infection rates in SIR models). Indeed, $\mathrm{TCI}$ (transient collective immunity - Tkacnenko et al. 2021) would emerge during early, high-paced stages of the pandemic and, therefore, leading to the decrease of each epidemic wave individually. Hence, TCI might be a better explanation for the consecutive waves in Manaus, and potentially an evolutionary scenario of greater chances of a mutant to survive stochastic extinction (as explained in Day et al. 2020). Hence, a substantial number of persons might still be susceptible after a first contact with the virus, and even more to a mutant variant, and especially in a city with the characteristics of Manaus.

\section{Acknowledgments}

S P. Ribeiro, Alexandre B. Reis, Aristóteles G. Neto, Vasco A.C. Azevedo and Geraldo W. Fernandes are researchers granted by CNPq. We thanks Hildeberto de Caldas Sousa for double checking on facts about life in Manaus. This study has no financial support.

\section{REFERENCES}

ANDREASEN V, VIBOUD C \& SIMONSEN L. 2008. Epidemiologic characterization of the 1918 Influenza pandemic summer wave in Copenhagen: implications for pandemic control strategies. J Infect Dis 197: 270-278.

ATLAS FGV. 2021. GRIPE ESPANHOLA. Available at: https:// atlas.fgv.br/verbetes/gripe-espanhola. accessed 10 March, 2021

BARBOSA LG, ALVES M \& GRELLE CEV. 2020. Actions against sustainability: dismantling of the environmental policies in Brazil. Land Use Pol 104: 105384.

BERNGRUBER TW, FROISSART R, CHOISY M \& GANDON S. 2013. Evolution of virulence in emerging epidemics. PLOS Pathog 9(1-8): e1003209.

BUSS LF ET AL. 2021. Three-quarters attack rate of SARS-CoV-2 in the Brazilian Amazon during a largely unmitigated epidemic. Science 371: 288-292.

BUCKLEY RM. 2020. Targeting the world's slums as fat tails in the distribution of COVID-19 Cases. J Urban Health 97: 358-364.

BUTLER JC ET AL. 2001. Emerging infectious diseases among indigenous peoples. Emerg Infec Dis 7: 554-555.

CALDAS JN \& POZZETTI VC. 2017. Hygienic and sanitarian conditions of Manaus ports, AM (Condições higiênicosanitárias dos portos de Manaus-AM), 2007-2010. Soc Ci Tecn 5: 53-59.

COUTINHO RM ET AL. 2021. Model-based estimation of transmissibility and reinfection of SARS-CoV-2 P.1 variant. medRxiv https://doi.org/10.1101/2021.03.03.21252706.

COVID-19.SOCIOAMBIENTAL 2021. Plataforma de monitoramento da situação indígena na pandemia do novo coronavírus (COVID-19) no Brasil. Disponível em https://covid19.socioambiental.org/. Accessed 28 Feb, 2021.

DAVIES NG ET AL. 2021. Estimated transmissibility and impact of SARS-CoV-2 lineage B.1.1.7 in England. Science 372: eabg3055. https://doi.org/10.1126/science.abg3055. 
DAY T, GANDON S, LION S \& OTTO SP. 2020. On the evolutionary epidemiology of SARS-CoV-2. Curr Biol 30: R849-R57.

FERRANTE L ET AL. 2021. Brazil's policies condemn Amazonia to a second wave of COVID-19. Nat Medic 26: 1315.

FERREIRA-DE-LIMA VH \& LIMA-CAMARA TN. 2018. Natural vertical transmission of dengue virus in Aedes aegypti and Aedes albopictus: a systematic review. Parasit Vectors 11: 77 https://doi.org/10.1186/s13071-018-2643-9.

FRASER B. 2020. How anti-science attitudes have impacted the coronavirus pandemic in Brazil. Sci Am May 22.

FVS/AM - FUNDAÇÃO DE VIGILÂNCIA EM SAÚDE DO AMAZONAS. 2020. Coronavírus: situação epidemiológica da COVID-19 no Estado do Amazonas, 2020. Bol Epidem 15: 1-2. Disponível em https://www.fvs.am.gov.br/media/ publicacao/Boletim_15_f84a1qO.pdf.

FVS/AM - FUNDAÇÃO DE VIGILÂNCIA EM SAÚDE DO AMAZONAS. 2021. Painel Covid-19 AMAZONAS. 2021. http://saude. am.gov.br/painel/corona/. accessed 2021 April 30.

GAGNON A, MILLER MS, HALLMAN SA, BOURBEAU R, HERRING DA, EARN DJD \& MADRENAS J. 2013. Age-specific mortality during the 1918 Influenza pandemic: unravelling the mystery of high young adult mortality. PLOS One 8: e69586. https:// doi.org/10.1371/journal.pone.0069586.

GAMA RM. 2020. Mephistophelic days: the Spanish flu in Manaus by the newspapers of 1918-1919. Dias mefistofélicos: a gripe espanhola em Manaus através dos jornais de 1918 - 1919. Editora dialética, Belo Horizonte (Brazil), 205 p.

HATCHETT RJ, MECHER CE \& LIPSICH M. 2007. Public health interventions and epidemic intensity during the 1918 influenza pandemic. PNAS 18: 7582-7587.

JOHANSSON MA, QUANDELACY TM, KADA S, PRASAD PV, STEELE M, BROOKS JT, SLAYTON RB, BIGGERSTAFF M \& BUTLER JC. 2021. SARS-CoV-2 transmission from people without COVID-19 symptoms. JAMA Net Open 4: e2035057.

JONES KE ET AL. 2008. Global trends in emerging infectious diseases. Nature 451: 990-994.

KARESH WB ET AL. 2012. Ecology of zoonoses: natural and unnatural histories. Lancet 380: 1936-1945.

LENSKI RE \& MAY RM. 1994. The evolution of virulence in parasites and pathogens: reconciliation between two competing hypotheses. J Theor Biol 169: 253-265.

LI R, PEI S, CHEN B, SONG Y, ZHANG T, YANG W \& SHAMAN J. 2020. Substantial undocumented infection facilitates the rapid dissemination of novel coronavirus (SARS-CoV-2). Science 368: 489-493.
LOANNIDIS JPA. 2020. Infection fatality rate of COVID-19 inferred from soroprevalence data. Bull. WHO Org. 99: 19-33F. https://doi.org/10.2471/BLT.20.265892.

MAY RM \& ANDERSON RM. 1983. Epidemiologic and genetics in the coevolution of parasites and hosts. Proc R Soc Lond B 219: 281-313.

MAROKO AR, NASH D \& PAVILONIS BT. 2020. COVID-19 and Inequity: a Comparative Spatial Analysis of New York City and Chicago Hot Spots. J Urban Health 97: 461-470.

MENA GE, MARTINEZ PP, MAHMUD AS, MARQUET PA, BUCKEE CO \& SANTILLANA M. 2021. Socioeconomic status determines COVID-19 incidence and related mortality in Santiago, Chile. Science: eabg5298. https://doi.org/10.1126/science. abg5298.

MISHRA SV, GAYEN A \& HAQUE SM. 2020. COVID-19 and urban vulnerability in India. Habitat Int 03: 102230.

OBSERVATÓRIO COVID-19. 2021. Informação para ação. Available at: https://portal.fiocruz.br/observatoriocovid-19. Accessed 03 March 2021.

REID AH, TAUBENBERGER JK \& FANNING TG. 2004 Evidence of an absence: the genetic origins of the 1918 pandemic influenza virus. Nat Rev Microbiol 2: 909-914.

RIBEIRO SP ET AL. 2020a. Severe Airport Sanitarian Control Could Slow down the Spreading of COVID-19 Pandemics in Brazil. PeerJ 8: e9446.

RIBEIRO SP ET AL. 2020b. Worldwide COVID-19 spreading explained: traveling numbers as a primary driver for the pandemic. An Acad Bras Cienc 92: e20201139. https://doi. org/10.1590/0001-3765202020201139.

SABINO EC ET AL. 2021. Resurgence of COVID-19 in Manaus, Brazil, despite high seroprevalence. Lancet 397(10273): 452-455.

SCHWARCZ M \& STARLING HM. 2020. A Bailarina da morte: a gripe espanhola no Brasil. Companhia das Letras, São paulo.

STEPHENSON E ET AL. 2021. Single-cell multi-omics analysis of the immune response in COVID-19. Nature Med 27: 904-916.

TAUBENBERGER JK \& MORENS DM. 2006. 1918 Influenza: the mother of all pandemics. Emerg Infect Dis 12: 15-22.

TAUBENBERGER JK, REID AH \& FANNING TG. 2000. The 1918 influenza virus: a killer comes into view. Virology 274 : 241-245.

TKACHENKO AV, MOSLOV S, ELBANNA A, WONG GN, WEINER ZJ \& GOLDENFELD N. 2021. Time-dependent heterogeneity 
leads to transient suppression of the COVID-19 epidemic, not herd immunity. PNAS 118: e2015972118.

TRANSPARÊNCIA COVID-19. 2021. Séries Temporais COVID-19 no Amazonas. http://www.fvs.am.gov.br/ indicadorSalaSituacao_view/69/2. Accessed 28 Feb, 2021.

\section{How to cite}

RIBEIRO SP, REIS AB, DÁTTILO W, CASTRO E SILVA AVC, BARBOSA EAG, COURA-VITAL W, GÓES NETO A, AZEVEDO VAC \& FERNANDES GW. 2021. From Spanish Flu to Syndemic COVID-19: long-standing sanitarian vulnerability of Manaus, warnings from the Brazilian rainforest gateway. An Acad Bras Cienc 93: e20210431. DOI 10.1590/0001-3765202120210431.

Manuscript received on March 22, 2021, accepted for publication on June 19, 2021

\section{SÉRVIO P. RIBEIRO $0^{1,2,3}$}

https://orcid.org/0000-0002-0191-8759

\section{ALEXANDRE B. REIS ${ }^{1,4}$}

https://orcid.org/0000-0001-8123-4164

\section{WESLEY DÁTTILO 5}

https://orcid.org/0000-0002-4758-4379

\section{ALCIDES V.C. DE CASTRO E SILVA ${ }^{6}$}

https://orcid.org/0000-0003-2863-8076

\section{EDUARDO AUGUSTO G. BARBOSA ${ }^{7}$}

https://orcid.org/0000-0001-5652-7344

\section{WENDEL COURA-VITAL ${ }^{1,8}$}

https://orcid.org/0000-0002-1434-7676

\section{ARISTÓTELES GÓES-NETO ${ }^{9}$}

https://orcid.org/0000-0002-7692-6243

\section{VASCO A.C. AZEVEDO ${ }^{10}$}

https://orcid.org/0000-0002-4775-2280

\section{GERALDO WILSON FERNANDES ${ }^{11}$ \\ https://orcid.org/0000-0003-1559-6049}

'Universidade Federal de Ouro Preto, Núcleo de Pesquisas em Ciências Biológicas - NUPEB, St. Três, 408-462, Bauxita, 35400-000 Ouro Preto, MG, Brazil

${ }^{2}$ Universidade Federal de Ouro Preto, Laboratory of Ecology of Diseases and Forests, Departamento de Biodiversidade, Evolução e Meio Ambiente, St. Quatro, 786, Bauxita, 35400-000 Ouro Preto, MG, Brazil

${ }^{3}$ Universidade Federal de Minas Gerais, Laboratory of Physiology of Hematophagous Insects, Departamento de Parasitologia, Ave. Pres. Antônio Carlos, 6627, Pampulha, 31270-901 Belo Horizonte, MG, Brazil
${ }^{4}$ Universidade Federal de Ouro Preto, Laboratory of Imunopatology, Departamento de Análises Clínicas, St. Três, 408-462, Bauxita, 35400-000 Ouro Preto, MG, Brazil ${ }^{5}$ Instituto de Ecología AC, Red de Ecoetología, Carretera Antigua a Coatepec, 351, El Haya, Xalapa, Veracruz, 91070 Mexico

${ }^{6}$ Universidade Federal de Ouro Preto, Laboratory of Complexity Science, Departamento de Física, St. Quatro, 786, Bauxita, 35400-000 Ouro Preto, MG, Brazil

${ }^{7}$ Centro Federal de Educação Tecnológica de Minas Gerais, Programa de Pós-Graduação em Modelagem Matemática e Computacional, 30510-000 Belo Horizonte, MG, Brazil

${ }^{8}$ Universidade Federal de Ouro Preto, Laboratory of Epidemiology and Citology, Departamento de Análises Clínicas, St. Nove, 27, Bauxita, 35400-000 Ouro Preto, MG, Brazil

${ }^{9}$ Universidade Federal de Minas Gerais, Laboratory of Molecular and Computational Biology of Fungi, Departamento de Microbiologia, Ave. Pres. Antônio Carlos, 6627, Pampulha, 31270-901 Belo Horizonte, MG, Brazil

${ }^{10}$ Universidade Federal de Minas Gerais, Laboratory of Cell and Molecular Genetics, Departamento de Genética, Ecologia e Evolução, Ave. Pres. Antônio Carlos, 6627, Pampulha, 31270-901 Belo Horizonte, MG, Brazil

${ }^{11}$ Universidade Federal de Minas Gerais, Laboratory of Evolutionary Ecology and Biodiversity, Departamento de Genética, Ecologia e Evolução, Ave. Pres. Antônio Carlos, 6627, Pampulha, 31270-901 Belo Horizonte, MG, Brazil

Correspondence to: Sérvio Pontes Ribeiro

E-mail:serviopr@gmail.com

\section{Author contributions}

SPR - Conceptualization; Data curation; Formal analysis; Investigation; Methodology; Project administration; Writingoriginal draft; Writing-review \& editing. WD - Formal analysis; Investigation; Validation; Writing-review \& editing. AVCCS - Formal analysis; Investigation; Writing-review \& editing. EAGB - Formal analysis. WCV - Formal analysis; Investigation; AGN - Investigation; Writing-review \& editing. VACA - Supervision; Writing-review \& editing. ABR - Project administration; Supervision; Writing-review \& editing. GWF Project administration; Supervision; Validation; Writing-review \& editing.

\section{(cc) BY}

